\title{
Horizontal R\&D Cooperation and Spillovers: Evidence from France
}

Désiré Vencatachellum, Bruno Versaevel

Octobre 2006

GATE Groupe d'Analyse et de Théorie Économique UMR 5824 du CNRS

93 chemin des Mouilles - 69130 Écully - France

B.P. $167-69131$ Écully Cedex

Tél. +33 (0)4 72866060 - Fax +33 (0)4 72866090

Messagerie électronique gate@gate.cnrs.fr

Serveur Web : www.gate.cnrs.fr 


\title{
Horizontal R\&D Cooperation and Spillovers: Evidence from France*
}

\author{
Désiré Vencatachellum \\ Bruno Versaevel
}

October 25, 2006

\footnotetext{
${ }^{*}$ Part of this note was written while Vencatachellum was visiting Ecole Normale Supérieure in Lyon, whose hospitality is gratefully acknowledged. Versaevel is grateful to the French ministry of industry for access to the data. We thank Pierre Mohnen for helpful comments. Vencatachellum: HEC Montreal, Université de Montréal, 3000, Cote-Ste-Catherine, Montreal (Quebec) Canada Email: dv@hec.ca. Versaevel: EM Lyon and GATE (UMR CNRS 5824), 23 Avenue Guy de Collongue, 69134 Ecully Cedex, France Email: versaevel@em-lyon.com.
} 


\begin{abstract}
We use the French portion of the 2002 Community Innovation Survey to test how spillovers affect the likelihood that firms cooperate in R\&D. Unlike most existing empirical studies, our results clearly support well-established theoretical predictions of the industrial organization literature. We find that a firm which benefits from higher spillovers from her rivals is more likely to cooperate horizontally in R\&D. Moreover, the impact of incoming spillovers on the likelihood of horizontal R\&D cooperation is positive and statistically significant only when they are above a threshold. Both the value, and the precision of the estimates, increase with the information flow which firms report receiving from their competitors.
\end{abstract}

Keywords: Cooperation, R\&D, Spillovers

JEL Classification: O31, O32, D21 


\section{Introduction}

The relationship between technological spillovers and the profitability of $R \& D$ cooperation has received much attention in the theoretical industrial organization literature. Most models consider oligopolistic firms which may cooperate in R\&D with rivals (i.e., horizontal cooperation), and which focus on costreducing R\&D (d'Aspremont and Jacquemin 1988, Kamien, Muller and Zang 1992, De Bondt 1997, among others). Although these models may have different setups, they all find that firms earn higher profits when they cooperate in $R \& D$ than when they do not. Moreover, the profitability of R\&D cooperation increases with the level of R\&D spillovers when they are sufficiently high. Another stream of the literature focuses on quality-improving $\mathrm{R} \& \mathrm{D}$ in models with vertical product differentiation (Motta 1992, Rosenkranz 1995). Although these papers differ from the cost-reducing R\&D models in some of their specifications, they also find that R\&D cooperation increases firms' profits.

While most analysis assume that R\&D spillovers are exogenous, more recent theoretical research allows firms to choose spillovers as a strategic variable (Amir, Evstigneev and Wooders 2003). The main message of these analysis is that firms which cooperate horizontally in R\&D generally find it profitable to maximize intra-industry spillovers. A few papers propose a dynamic model of firms' choice to cooperate in R\&D (Kesteloot and Veugelers 1995). When incoming spillovers are distinguished from outgoing ones, it is found that only the latter may result in higher incentives to free ride on R\&D partners while incoming spillovers increase the attractiveness of cooperation. This leads to the theoretical prediction that horizontal $\mathrm{R} \& \mathrm{D}$ cooperation is more likely to be observed the higher the spillovers coming from rivals.

Surprisingly, these well-established theoretical results have received very little empirical support. Only a few papers investigate the empirical link between R\&D spillovers and R\&D cooperation. Those which do so reach mixed results. As most existing analysis use relatively small data sets, they cannot distinguish between cooperative agreements exclusively among competitors in the same industry from 
other possible types of partners (suppliers, customers, universities, independent labs). Kaiser (2002) considers three categories of R\&D agreements: horizontal, vertical (with customers and /or suppliers), and mixed, i.e. those which are horizontal and vertical. He finds that horizontal spillovers have a weakly significantly positive effect on firms' propensity to cooperate while they do not significantly affect the choice of vertical or mixed cooperation. However, as Kaiser's (2002) analysis concerns only the German service sector it may be difficult to extrapolate the results to the whole population of firms. Moreover, as only few firms (that is, 36 firms) cooperate horizontally, they are included in the mixed agreements category (Kaiser 2002, p. 760). Cassiman and Veugelers (2002) use Flemish data to find that firms which benefit the most from public information sources are more likely to cooperate in R\&D. However, they cannot investigate horizontal cooperation separately because only 33 firms in their survey cooperated in R\&D with competitors (Cassiman and Veugelers 2002, footnote 10, page $1172)$.

New and sharper results appear in a recent paper by Belderbos, Caree, Diederen, Lokshin and Veugelers (2004), who construct a multivariate probit model to explore differences in the determinants of innovating firms' decisions to participate in three distinct types of cooperation (with competitors, with suppliers or customers, with universities and research institutes). ${ }^{1}$ With a large Dutch dataset (627 firms with R\&D cooperation of some type), it is found that incoming spillovers, which specifically originate from competitors, are statistically significant (at the $10 \%$ level) in explaining R\&D cooperation with firms from the same industry.

We contribute to this emerging empirical literature by using French data from the 2002 Community Innovation Survey (CIS), which is conducted in member countries of the European Union, to investigate the link between horizontal R\&D cooperation and R\&D spillovers among competitors. The objective of this note is twofold. First, we test the robustness of existing empirical results to the use of a larger and

\footnotetext{
${ }^{1}$ We refer the reader to Belderbos et. al. (2004) for a thorough survey of the theoretical and empirical literatures on horizontal R\&D cooperation.
} 
more recent dataset. Second, we exploit the link between a non-binary detailed measure of information firms receive from competitors and their incentive to engage in horizontal R\&D agreements to obtain new insights.

Our first main finding is that firms are more likely to cooperate horizontally the more they benefit from competitors in the industry as their main source of information to innovate. This confirms the findings of Belderbos et al. (2004). In addition, we establish two completely new results. First, we find that incoming spillovers have a significant positive impact on the likelihood that a firm cooperates horizontally in R\&D only when these spillovers exceed a threshold. Second, the estimates of the impact of spillovers on the decision to cooperate, together with their precisions, are increasing in the value of the measure of information flow.

The remainder of the paper is organized as follows. Section 2 describes the empirical model and data. We then discuss the results in section 3 and conclude in section 4 . Tables 1 and 2 are in the appendix.

\section{Model and data}

Denote by $m$ the R\&D organizational mode, with $m=0$ if a firm does not cooperate horizontally in $\mathrm{R} \& \mathrm{D}$, and $m=1$ if she does. Let $\pi^{m}(s, \boldsymbol{x})$ denote a firm's profits as a function of technological spillovers $s$ and a vector of characteristics $\boldsymbol{x}$. The benefits from cooperation are given by the difference:

$$
\begin{aligned}
\Delta(s, \boldsymbol{x}) & =\pi^{1}(s, \boldsymbol{x})-\pi^{0}(s, \boldsymbol{x})+\varepsilon, \\
& =s \gamma+\boldsymbol{x} \boldsymbol{\beta}+\varepsilon,
\end{aligned}
$$

where $\varepsilon$ is a mean-zero normally distributed error term which captures the impact of unobservables on the benefits of cooperation, $\gamma$ is a parameter and $\boldsymbol{\beta}$ is a vector of parameters. The second line of (1) is 
a linear approximation of the difference in profits when a firm cooperates versus does not cooperate. $\Delta(s, \boldsymbol{x})$ is not observable but a firm chooses:

$$
m=\left\{\begin{array}{c}
1 \text { if } \varepsilon \geq-(s \gamma+\boldsymbol{x} \boldsymbol{\beta}) \\
0 \text { if } \varepsilon<-(s \gamma+\boldsymbol{x} \boldsymbol{\beta})
\end{array}\right.
$$

Equation (2) is a simple probit model. The null hypothesis of interest is $\gamma=0$ which can be tested by using the 2002 CIS data for France.

The survey includes a representative sample of 7,016 establishments in France. Firms reported whether they had any cooperation arrangements on innovation activities between 1998 and 2000. There are 3,830 firms for which we know whether they cooperated or not. ${ }^{2}$ This constitutes a larger dataset than the ones used in existing studies on the same topic. We distinguish between cooperative arrangements with any type of partner (1,511 firms) and cooperative arrangements only with competitors and other firms from the same industry (376 firms). This distinction allows us to focus on horizontal cooperation, which is the subject of the theoretical literature of interest. While rivals choose to cooperate in order to maximize their individual profits, this is not necessarily the case for establishments within the same group, where profits are consolidated, or for firm-university agreements.

The relevant summary statistics, differentiated by whether firms do not cooperate, cooperate with any type of partner, or cooperate horizontally, are given in Table 1. Firms which cooperate are on average much bigger, and export more, than those which do not. The share of firms which innovated by cooperating with other firms in the past is highest for those which report cooperating horizontally between 1998 and 2000. There is no significant difference in the percentage of multinationals which

\footnotetext{
${ }^{2}$ The survey lists 9 possible partners: Other enterprises within your enterprise group; Suppliers of equipment, materials, components or software; Clients or customers; Competitors and other firms from the same industry; Consultants; Commercial laboratories/R\&D enterprises; Universities; and Government or private non-profit research institutes (see section 8.2 of the third CIS harmonized questionnaire).
} 
do not cooperate or those which choose to cooperate with any type of partner or horizontally. Firms which cooperate horizontally have the highest R\&D intensity.

As suggested by Cassiman and Veugelers (2002, p. 1169) and Belderbos et al. (2004, pp. 1245-6), we distinguish between horizontal firm-level and industry-level incoming spillovers. As in the latter papers, we can proxy R\&D spillovers among competitors by using a specific feature of the CIS questionnaire. Firms were asked to rank from 0 (unimportant) to 3 (highest) if "information from competitors and other enterprises from the same industry" is a source for innovation. ${ }^{3}$ We use that variable as a direct measure of firm-level incoming spillovers, and average the scores at the NACE 2-digit sector level for industry-level incoming spillovers. Given our focus on horizontal cooperation, these measures allow us to better capture technological spillovers as commonly understood in the theoretical literature.

We need to control for other factors which potentially incite firms to cooperate, so as to isolate the effect of horizontal incoming spillovers. We draw from the literature mentioned above to identify the explanatory variables, and list them in the first column of Table 2. In particular, we control for firm participation in cooperative agreements with other types of partners. However, we acknowledge that we cannot fully account for firm-specific unobserved characteristics. Doing so would require panel data as in Belderbos et. al. (2004). Unfortunately, given that the questionnaires used in the successive waves of the Community Innovation Survey for France differ significantly, such an option is not possible. ${ }^{4}$ Harmonizing future surveys should help address this issue and confirm the extent to which our results are robust. The next section discusses our estimates.

\footnotetext{
${ }^{3}$ Information from competitors and other enterprises from the same industry as a source of innovation does not appear in the Belgian 1993 survey used by Cassiman and Veugelers (2002, p. 1171) who refer to three sources of information: (i) patents; (ii) specialist conferences, meetings and publications; (iii) trade shows and seminars.

${ }^{4}$ The question on sources of information used in various types of R\&D cooperation lists 12 possibilities in the 1997 CIS and only 9 possibilities in the 2002 CIS.
} 


\section{Results}

The results in Table 2 are for two types of dependent variables: models 1-A and 1-B concern cooperation with all types of partners; models $2-\mathrm{A}$ and 2-B are for cooperation among rival firms only. For each type of dependent variable we consider two specifications for the source of information for innovation "from competitors and other firms from the same industry": (A) the respondent's score, and (B) a dummy variable for each of the three values of that variable. This distinction allows us to capture potential non-linearity, and threshold effect, in how that variable affects the incentives for firms to cooperate horizontally in $\mathrm{R} \& \mathrm{D}$.

We find that none of the sources of information which firms used to innovate between 1998 and 2000 reduces their likelihood of cooperating in R\&D. Only the sources from competitors, from other establishments within the same group, and from universities, are statistically significant in explaining R\&D cooperation at large, i.e. when partners are not discriminated. Sources from other establishments within the same group matter for cooperation only when we do not distinguish among types of partners. In other words, this type of information is only relevant for cooperation among establishments within the same group and is not useful for horizontal cooperation.

When cooperation is with any type of partner, firm-level incoming spillovers have no statistically positive effect on the likelihood that firms cooperate (model 1-A). However, when we restrict R\&D cooperation to competitors only, these spillovers do have a statistically positive effect on the likelihood that firms cooperate in R\&D (model 2-A). These results are robust to allowing for potential endogenous spillovers at the firm-level, but the size of the coefficient increases significantly. Cassiman and Veugelers (2002, p. 1175) also find that accounting for potential endogeneity increases the size of their estimates.

Our main results are obtained at a finer level of analysis. We find that firm-level incoming spillovers are still not statistically significant in model 1-B. Interestingly, in model 2-B these spillovers are not 
significant when they are low. However, they have a significant and increasingly positive impact on the likelihood that a firm cooperates in $R \& D$ when they exceed a threshold. When the reported level of incoming spillovers is low, their impact on the likelihood to cooperate with rivals is only sligtly positive $(+0.098)$ and not significant. When the level is intermediate, the impact is higher $(+0.318)$ and significant (at the $5 \%$ level). When respondents report the highest level of incoming spillovers, the impact is even higher $(+0.466)$ and more significant (at the $1 \%$ level). These estimates, together with the associated statistical significativity, are consistent with the theoretical prediction that the profitability of $R \& D$ cooperation increases with the level of $R \& D$ spillovers when they are sufficiently high.

Concerning the other explanatory variables of cooperation in R\&D, we find that firms which benefited from central government or European Union public funding are more likely to cooperate than those which received no funding. It is not surprising that larger firms, and those where a larger share of their personnel do $R \& D$ ( $R \& D$ intensity), are more likely to cooperate. These findings suggest that a threshold level of financial and human resources is necessary for firms to cooperate in R\&D. Moreover, firms which successfully innovated by cooperating with other firms or institutions are more likely to cooperate in $\mathrm{R} \& \mathrm{D}$. This means that conditional on a successful experience, cooperation in $\mathrm{R} \& \mathrm{D}$ is persistent. Finally, the multinational dummy is never statistically significant in all specifications. 


\section{Conclusion}

The theoretical industrial organization literature finds that firms which benefit from high R\&D spillovers are more likely to cooperate horizontally in R\&D. We use the large dataset produced by the 2002 Community Innovation Survey for France to test this result. As in Belderbos et al. (2004), who use Dutch data, we find that a firm which benefits from higher spillovers from her rivals is more likely to cooperate in $\mathrm{R} \& \mathrm{D}$ with her competitors. A specific feature of our paper is that it exploits a three-level measurement of the magnitude of incoming spillovers as directly reported by firm respondents. We obtain that incoming spillovers have a positive and significant impact on the likelihood that a firm cooperates horizontally in R\&D only when they exceed a threshold. Moreover, we find that both the probability of inter-firm cooperation and the degree of significativeness of estimations increase with the level of a discrete scaling of received information flows from competitors. This offers new support to well-established theoretical predictions. 


\section{References}

Amir, Rabah, Igor Evstigneev, and John Wooders (2003) 'Noncooperative versus cooperative R\&D with endogenous spillover rates.' Games and Economc Behavior 42(2), 183-207

Belderbos, Rene, Martin Caree, Bert Diederen, Boris Lokshin, and Reinhilde Veugelers (2004) 'Heterogeneity in R\&D cooperation strategies.' International Journal of Industrial Organization $22(8), 1237-63$

Cassiman, Bruno, and Reinhilde Veugelers (2002) 'R\&D cooperation and spillovers: Some empirical evidence from Belgium.' American Economic Review 92(4), 1169-1184

d'Aspremont, Claude, and Alexis Jacquemin (1988) 'Cooperative and noncooperative R\&D in duopoly with spillovers.' American Economic Review 78(5), 1133-1137

De Bondt, Raymond (1997) 'Spillovers and innovative activities.' International Journal of Industrial Organization 15(1), 1-28

Kaiser, Ulrich (2002) 'An empirical test of models explaining R\&D expenditures and R\&D cooperation.' International Journal of Industrial Organization 20(6), 747-774

Kamien, Morton, Eitan Muller, and Israel Zang (1992) 'Research joint ventures and R\&D cartels.' American Economic Review 82(5), 1293-1306

Kesteloot, Katrien, and Reinhilde Veugelers (1995) 'Stable R\&D cooperation with spillovers.' Journal of Economics and Management Strategy 4(4), 333-357

Motta, Massimo (1992) 'Cooperative R\&D and vertical product differentiation.' International Journal of Industrial Organization 10(4), 643-661

Rosenkranz, Stephanie (1995) 'Innovation and cooperation under vertical product differentiation.' International Journal of Industrial Organization 13(1), 1-22 
Table 2: Probit Estimates of the Determinants of R\&D Cooperation

2002 Community Innovation Survey (CIS) -- France

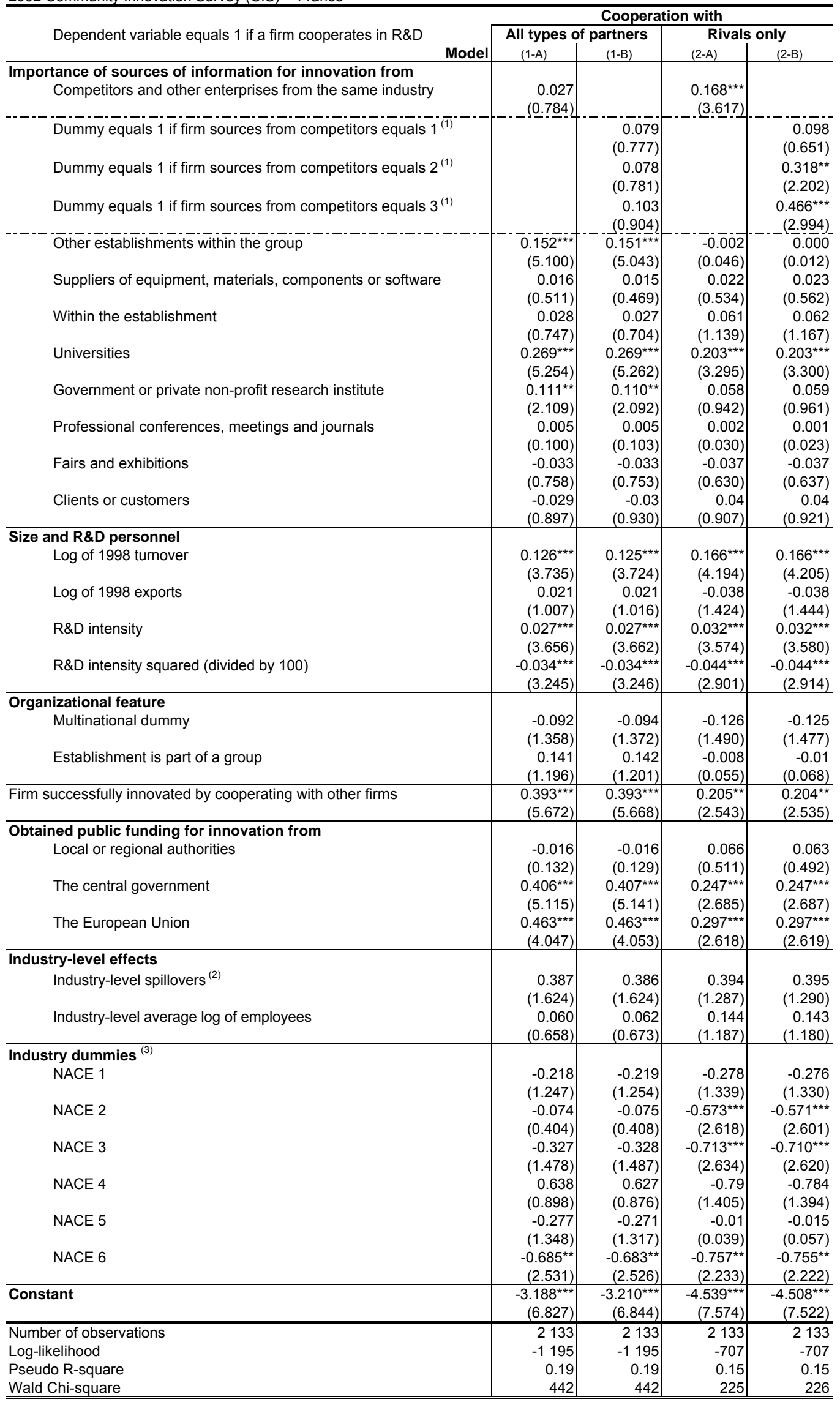

Notes Absolute vales of robust t-ratios are in parentheses. * significant at $10 \%$; ${ }^{* *}$ significant at $5 \%$; ${ }^{* * *}$ significant at $1 \%$

(1) The reference group is composed of firms for which the source of information from competitiors is not relevant.

(2) See footnote 4 of Table 1.

(3) The industry is defined at the NACE 1-digit sector level. The reference industry is NACE 7. 
Table for the referees only: Accounting for endogenous firm-level spillovers

\begin{tabular}{|c|c|c|}
\hline Dependent variable & $\begin{array}{l}\text { OLS First stage } \\
\text { Firm-level spillovers }{ }^{(1)}\end{array}$ & $\begin{array}{c}\text { Probit Second stage } \\
\text { Model (2-A BIS })^{(1)}\end{array}$ \\
\hline \multicolumn{3}{|l|}{ Importance of sources of information for innovation from } \\
\hline \multicolumn{2}{|l|}{ Fitted values of Competitors and other enterprises from the same industry } & $\begin{array}{r}1.920^{* \star \star} \\
(3.925)\end{array}$ \\
\hline $\begin{array}{l}\text { Other establishments within the group } \\
\text { Suppliers of equipment, materials, components or software } \\
\text { Within the establishment } \\
\text { Universities } \\
\text { Government or private non-profit research institute } \\
\text { Professional conferences, meetings and journals } \\
\text { Fairs and exhibitions } \\
\text { Clients or customers }\end{array}$ & & $\begin{array}{r}0.011 \\
(0.296) \\
0.029 \\
(0.696) \\
0.066 \\
(1.208) \\
0.200^{\star \star *} \\
(3.191) \\
0.068 \\
(1.083) \\
0.054 \\
(0.849) \\
-0.04 \\
(0.672) \\
0.093^{\star *} \\
(2.230)\end{array}$ \\
\hline $\begin{array}{l}1998 \text { turnover } \\
1998 \text { turnover square (divided by } 1,000,000 \text { ) } \\
\text { Share of new or improved products to market }\end{array}$ & $\begin{array}{r}0.089^{\star \star *} \\
(2.699) \\
-2.01^{*} \\
(1.723) \\
0.257^{*} \\
(1.901) \\
\end{array}$ & \\
\hline $\begin{array}{l}\text { Size and R\&D personnel } \\
\text { Log of } 1998 \text { turnover } \\
\text { Log of } 1998 \text { exports } \\
\text { R\&D intensity } \\
\text { R\&D intensity squared (divided by } 100 \text { ) }\end{array}$ & & $\begin{array}{r}0.098^{* *} \\
(2.337) \\
-0.028 \\
(1.063) \\
0.028^{\star * \star} \\
(3.158) \\
-0.000^{* \star *} \\
(2.644) \\
\end{array}$ \\
\hline $\begin{array}{l}\text { Organizational feature } \\
\text { Multinational dummy } \\
\text { Establishment is part of a group }\end{array}$ & $\begin{array}{r}0.282^{* \star *} \\
(6.103) \\
\end{array}$ & $\begin{array}{r}-0.141 \\
(1.641) \\
-0.449^{\star *} \\
(2.323) \\
\end{array}$ \\
\hline Firm successfully innovated by cooperating with other firms & & $\begin{array}{l}0.207^{\star \star} \\
(2.488)\end{array}$ \\
\hline $\begin{array}{l}\text { Obtained public funding for innovation from } \\
\text { Local or regional authorities } \\
\text { The central government } \\
\text { The European Union }\end{array}$ & & $\begin{array}{r}0.055 \\
(0.424) \\
0.229^{\star *} \\
(2.416) \\
0.250^{\star *} \\
(2.119) \\
\end{array}$ \\
\hline $\begin{array}{l}\text { Industry-level effects } \\
\text { Industry-level spillovers }{ }^{(2)} \\
\text { Industry-level average log of employees }\end{array}$ & & $\begin{array}{r}0.468 \\
(1.497) \\
0.182 \\
(1.435) \\
\end{array}$ \\
\hline $\begin{array}{c}\text { Industry dummies }{ }^{(3)} \\
\text { NACE } 1\end{array}$ & $\begin{array}{r}0.297^{\star \star *} \\
(4.129)\end{array}$ & $\begin{array}{r}-0.845^{* * *} \\
(3.429)\end{array}$ \\
\hline NACE 2 & $\begin{array}{r}0.368^{\star * \star} \\
(5.754)\end{array}$ & $\begin{array}{r}-1.282^{* * *} \\
(4.474)\end{array}$ \\
\hline NACE 3 & $\begin{array}{r}0.541^{* \star *} \\
(7.694)\end{array}$ & $\begin{array}{r}-1.795^{\star * *} \\
(4.635)\end{array}$ \\
\hline NACE 4 & $\begin{array}{r}0.409^{*} \\
(1.729)\end{array}$ & $\begin{array}{r}-1.798^{* \star *} \\
(2.661)\end{array}$ \\
\hline NACE 5 & $\begin{array}{c}-0.017 \\
(0.167)\end{array}$ & $\begin{array}{r}-0.045 \\
(0.161)\end{array}$ \\
\hline NACE 6 & $\begin{array}{r}0.584^{* \star *} \\
(5.960) \\
\end{array}$ & $\begin{array}{r}-1.920^{\star * *} \\
(4.233) \\
\end{array}$ \\
\hline Constant & $\begin{array}{r}0.938^{\star \star *} \\
(14.605)\end{array}$ & $\begin{array}{r}-6.011^{\star \star \star} \\
(8.405)\end{array}$ \\
\hline Number of observations & 3315 & 2026 \\
\hline $\begin{array}{l}\text { Notes }{ }^{(1)} \text { The dependent variable is the score } 0,1,2 \text { or } 3 \text { which a firm ass } \\
\text { for innovation from competitors and the model is estimated by OL } \\
\text { (2) The dependent variable equals } 1 \text { if a firm cooperates with her } r\end{array}$ & $\begin{array}{l}\text { to the importance of } \mathrm{s} \\
\text { in Cassiman and Veu } \\
\text { and } 0 \text { otherwise. }\end{array}$ & $\begin{array}{l}\text { sources of information } \\
\text { ugelers (2002). }\end{array}$ \\
\hline
\end{tabular}

